\title{
Peningkatan Hasil Belajar IPA pada Pembelajaran Tema 9 Melalui Model Discovery Learning Berbantuan Media Powerpoint bagi Siswa Kelas V SDN 2 Tanggung
}

\author{
Mila Deviana*, Ervina Eka Subekti, Kuswandari \\ PPG Pra jabatan, Pendidikan Guru Sekolah Dasar, Universitas PGRI Semarang \\ *Corresponding Author. Email: miladevyana1@gmail.com
}

\begin{abstract}
This study aims to improve the learning outcomes of fifth graders at SDN 2 Responsibilities in science subjects with the discovery learning model assisted by power point media. This research method used classroom action research with 3 cycles. The subjects of this study were the fifth grade students at SDN 2 Responsibility with a total of 26 people. Data collection techniques are carried out through interviews, observation, documentation. The data analysis technique used descriptive analysis. The results of this study are that there is an increase in the percentage of students' science mastery learning outcomes, from the first cycle to the third cycle there is an increase in the percentage of science learning mastery outcomes by $73 \%$. So the conclusion obtained from the results of this study is that the discovery learning model assisted by power point media can improve the learning outcomes of fifth grade students of SDN 2 Responsibility in science subjects.
\end{abstract}

\begin{abstract}
Abstrak: Penelitian ini bertujuan untuk meningkatkan hasil belajar siswa kelas V SDN 2 Tanggung pada mata pelajaran IPA dengan model discovery learning berbantuan media power point. Metode penelitian ini menggunakan penelitian tindakan kelas dengan dengan 3 siklus. Subjek penelitian ini adalah siswa kelas V di SDN 2 Tanggung dengan jumlah 26 orang. Teknik pengumpulan data yang dilakukan yaitu melalui wawancara, observasi, dokumentasi. Teknik analisis datanya menggunakan analisis deskriptif. Hasil dari penelitian ini yaitu terdapat kenaikan presentase ketuntasan hasil belajar IPA siswa, dari siklus pertama sampai siklus ketiga mengalami kenaikan presentase ketuntasan hasil belajar IPA sebesar $73 \%$. Sehingga kesimpulan yang didapat dari hasil penelitian ini bahwa model discovery learning berbantuan media power point dapat meningkatkan hasil belajar siswa kelas V SDN 2 Tanggung pada mata pelajaran IPA.
\end{abstract} Article History

Received: 23-05-2021

Revised: 23-06-2021

Accepted: 24-06-2021

Published: 07-07-2021

\begin{abstract}
Key Words:
Science Learning

Outcomes, Discovery

Learning, PowerPoint

Media
\end{abstract}

\section{Sejarah Artikel}

Diterima: 23-05-2021

Direvisi: 23-06-2021

Disetujui: 24-06-2021

Diterbitkan: 07-07-2021

\section{Kata Kunci:}

Hasil Belajar IPA,

Discovery Learning,

Media Powerpoint.

How to Cite: Deviana, M., Subekti, E., \& Kuswandari, K. (2021). Peningkatan Hasil Belajar IPA pada Pembelajaran Tema 9 Melalui Model Discovery Learning Berbantuan Media Powerpoint bagi Siswa Kelas V SDN 2 Tanggung. Jurnal Paedagogy, 8(3), 345-350. doi:https://doi.org/10.33394/jp.v8i3.3891

https://doi.org/10.33394/jp.v8i3.3891

This is an open-access article under the CC-BY-SA License.

\section{Pendahuluan}

Kemdikbud (2014) dalam materi pelatihan guru implementasi Kurikulum 2013, dijelaskan bahwa kurikulum 2013 berorientasi pada penguasaan kompetensi secara holistik yang menggunakan model pembelajaran untuk jenjang sekolah dasar adalah pembelajaran tematik integratif, yaitu pembelajaran yang mengintegrasikan berbagai mata pelajaran ke dalam satu tema, yang kemudian dikembangkan lagi ke dalam anak tema atau subtema. Berdasarkan hasil observasi yang dilakukan pada kelas V SDN 2 Tanggung pada saat pembelajaran berlangsung, kurang maksimalnya penerapan kurikulum 2013 dengan model pembelajaran yang kreatif inovatif dan guru kurang dalam memadukan berbagai muatan pelajaran ke dalam tema yang sudah ditentukan. Kendala lain yang dialami adalah kurangnya keaktifan dan tanggung jawab peserta didik dengan pekerjaan atau tugas yang diberikan oleh guru, hal ini yang menyebabkan rendahnya hasil belajar peserta didik 
khususnya pada mata pelajaran IPA. Hasil belajar IPA peserta didik kelas V SD N 2 Tanggung masih banyak yang dibawah Kriteria Ketuntasan Minumum (KKM). KKM mupel IPA di SD N 2 Tanggung yaitu sebesar 65.

Untuk mengatasi permasalahan tersebut, perlu adanya upaya untuk meningkatkan hasil belajar khususnya pada mata pelajaran IPA dengan mengembangkan suatu pembelajaran yang kreatif dan inovatif sehingga masalah tersebut dapat diatasi dan tujuan pembelajaran dapat dicapai. Guru harus dapat melaksanakan dan mencapai target kurikulum yang telah ditetapkan. Tetapi ketercapaian dalam target kurikulum tidak selalu menjamin pembelajaran tersebut dapat berkualitas. Kualitas pembelajaran dapat dipengaruhi oleh beberapa faktor. Secara langsung, kualitas pembelajaran dapat dilihat dari perilaku guru sebagai pendidik, perilaku dan dampak belajar siswa sebagai peserta didik, iklim pembelajaran, materi pembelajaran, media pembelajaran yang digunakan, serta sistem pembelajaran atau kurikulum. Untuk meningkatkan kualitas pembelajara, maka masing-masing komponen harus diupayakan agar berperan secara optimal. Berdasarkan refleksi awal gambaran yang terjadi di SDN 2 Tanggung dengan tim kolaborasi melalui data dokumen, observasi dan catatan lapangan, bahwa pembelajaran muatan IPA didapatkan hasil bahwa proses pembelajaran yang dilakukan secara daring karena adanya pandemi Covid-19 ini kurang meningkatkan kreativitas siswa. Guru masih saja hanya menggunakan metode ceramah dalam proses pembelajaran melalui WhatssApp. Proses pembelajaran yang berlangsung mempunyai kesan kaku dan didominasi oleh guru. Padahal hasil guru dalam kegiatan pembelajaran sangat berpengaruh terhadap kualitas pembelajaran. Hal tersebut terjadi karena guru belum menerapkan model pembelajaran yang inovatif dan belum memanfatkan media pembelajaran yang inovatif, sehingga berdampak pada respon dan hasil belajar siswa yang cenderung rendah. Kegiatan yang dilakukan siswa hanya membaca dan mengerjakan tugas yang diberikan guru melalui WhatssApp.

Berdasarkan observasi tersebut, untuk memecahkan masalah pembelajaran tersebut dibutuhkan alternatif tindakan untuk meningkatkan kualitas pembelajaran melalui Google meet dan penerapan model pembelajaran. Pada penelitian ini diterapkan model pembelajaran yakni Discovery Learning. Menurut Budiningsih (2005), Discovery Learning adalah cara belajar memahami konsep, arti, dan hubungan melalui proses intuitif untuk akhirnya sampai kepada suatu kesimpulan. Selanjutnya, Mulyasa (2013) menjelaskan bahwa discovery learning adalah suatu model pembelajaran guna mengembangkan belajar siswa yang aktif dengan menemukan sendiri, menyelidiki sendiri, maka hasil yang diperoleh akan setia dan tahan lama dalam ingatan, tidak mudah dilupakan siswa. Berdasarkan pendapat diatas dapat disimpulkan bahwa discovery learning adalah suatu pembelajaran yang proses pembelajarannya dalam penyampaian materinya disajikan secara tidak lengkap dan mendorong siswa untuk terlibat aktif menemukan sendiri informasi, serta konsep-konsep dan juga prinsip-prinsip, melalui percobaan dan pembelajaran secara langsung (Nuryaningsih, 2021; Nurmiati, 2020; Susmiati, 2020; Fitriana, 2019; Setiarini, 2016).

Selain penggunaan model pembelajaran, dalam penelitian ini juga menggunakan media pembelajaran untuk menunjang alat pembelajaran. Sanaky (2013) menjelaskan bahwa "media pembelajaran merupakan sebuat alat yang berfungsi dan dapat digunakan untuk menyampaikan pesan pembelajaran." Sedangkan pandangan Rossi dan Breidle dalam Sanjaya (2012) mengemukakan bahwa media pembelajaran adalah seluruh alat dan bahan yang dapat dipakai untuk tujuan pendidikan seperti radio, televisi, buku, koran, majalah, dan sebagainya. Berdasarkan pendapat tersebut dapat ditarik kesimpulan bahwa media 
pembelajaran merupakan fasilitas dalam pembelajaran yang digunakan sebagai perantara atau pengantar secara komunikasi yang digunakan guru untuk menyampaikan pesan informasi pembelajaran. Pada penelitian ini menggunakan media berupa Power Point. Menurut pendapat Arsyad (2014) menyatakan bahwa Power Point merupakan aplikasi yang banyak dipergunakan oleh orang-orang untuk mempresentasikan bahan ajar atau laporan, karya, atau status mereka.

Adapun penelitian yang relevan sebelumnya dilakukan oleh Gina Rosarina bersama Ali Sudin dan Atep Sujana (2014) dengan judul "Penerapan Model Discovery Learning Untuk Meningkatkan Hasil Belajar Siswa Pada Materi Perubahan Wujud Benda". Hasil penelitian tersebut menunjukkan bahwa dengan menerapkan model discovery learning merupakan suatu alternatif untuk meningkatan hasil belajar siswa, khususnya pada materi perubahan wujud benda. Penelitian yang dilakukan gina ini memiliki kesamaan dengan penelitian yang akan peneliti lakukan, yaitu sama-sama menerapkan Model Discovery Learning dan meningkatkan hasil belajar. Menurut Dimyati dan Mudjiono (2013) hasil belajar merupakan hasil dari suatu interaksi tindak belajar dan tindak mengajar. Dalam hal ini guru bertindak memberikan pengajaran dan diakhiri dengan proses evaluasi hasil belajar. Perubahan yang terjadi pada diri siswa, baik yang menyangkut aspek kognitif, afektif, dan psikomotor sebagai hasil dari belajar (Susanto, 2013; Suarni et al, 2021). Dapat ditarik kesimpulan bahwa hasil belajar merupakan kemampuan yang diperoleh siswa setelah melakukan kegiatan pembelajaran dengan menyelesaikan evaluasi. Evaluasi atau penilaian ini dapat dijadikan sebagai feedback atau tindak lanjut untuk mengukur tingkat penguasaan materi pembelajaran pada siswa.

Berdasarkan permasalahan yang ada dilapangan tersebut, maka sebagai seorang pendidik perlu berinovasi untuk dapat mengembangkan perencanaan pembelajaran yang dapat meningkatkan hasil belajar siswa. Adapun Penelitian ini bertujuan untuk meningkatkan hasil belajar siswa kelas V SDN 2 Tanggung pada mata pelajaran IPA dengan model discovery learning berbantuan media powerpoint.

\section{Metode Penelitian}

Metode penelitian yang digunakan adalah penelitian tindakan kelas yaitu penelitian yang bersifat kaloboratif atau kooperatif, artinya dalam pelaksanaannya terdapat kerja sama antara peneliti (guru) dan pihak lain demi keabsahan dan tercapainya tujuan penelitian. Aqib (2010) menjelaskan bahwa penelitian tindakan kelas merupakan penelitian yang dilakukan oleh guru di kelas (sekolah) tempat ia mengajar dengan penekanan untuk penyempurnaan atau peningkatan proses dan praksis dalam pembelajaran. Sedangkan menurut Mundilarto (2004), penelitian tindakan kelas ialah sebuah penelitian yang dilakukan oleh pendidik di kelasnya sendiri dengan jalan merancang, melaksanakan dan merefleksikan tindakan secara kolaboratif dan partisipasif dengan tujuan untuk memperbaiki kinerjanya sebagai tenaga pendidik sehingga hasil belajar siswanya untuk dapat meningkat. Subjek penelitian tindakan kelas ini ialah peserta didik kelas V SD N 2 Tanggung tahun ajaran 2020/2021, adapun jumlah peserta didik yang dimaksud adalah 26 siswa yang terdiri dari 16 laki-laki dan 10 perempuan.

Penelitian ini dilaksanakan dengan beberapa siklus, pada setiap siklus terdapat tahapan yaitu; perencanaan, pelaksanaan, pengamatan, dan refleksi. Pada tahap perencanaan guru membuat rencana pembelajaran dengan menerapkan model Discovery Learning, menyiapkan media pembelajaran dengan PPT, meyiapkan alat evaluasi, dan LKPD. Pada tahap pelaksanaan guru melaksanakan pembelajaran melalui GoogleMeet dengan 
menerapkan model Discovery Learning. Tahap Pengamatan yaitu melakukan pengamatan terhadap hasil belajar IPA yang telah dikerjakan oleh siswa, dan pada tahap refleksi dilakukan refleksi untuk mengetahui kekurangan dalam kegiatan untuk diperbaiki dalam siklus selanjutnya. Tahap-tahap tersebut dilaksanakan pada tiap siklus. Jenis data yang diperoleh yaitu melalui nilai ulangan harian siswa pada mupel IPA. Sumber data yang dikumpulkan dalam penelitian ini meliputi: Narasumber, yaitu guru kelas dan siswa kelas V SD N 2 Tanggung, tempat berlangsungnya proses pembelajaran, dokumen yaitu berupa presensi siswa, daftar nilai dan dokumen lainnya yang dapat dijadikan sumber data yang valid dalam penelitian. Teknik pengumpulan data yang dilakukan yaitu melalui wawancara, observasi, dokumentasi. Hasil belajar siswa diketahui melalui ulangan harian pada mapel IPA. Adapun teknik analisis data penelitian ini menggunakan analisis deskriptif.

\section{Hasil Penelitian dan Pembahasan}

Hasil penelitian ini didasarkan pada hasil belajar IPA peserta didik serta refleksi setiap pertemuan di tiap siklus pada proses pembelajaran pada tema Benda-benda di Sekitar Kita melalui model Discovery Learning berbantu media Power Point. Sebelum melakukan tindakan, peneliti melakukan observasi kondisi awal siswa kelas V SD N 2 Tanggung, pada kondisi awal ini diperoleh data bahwa nilai rata-rata yang diperoleh siswa adalah 50 yang berarti masih di bawah KKM yaitu 65, selain itu pada proses pembelajaran guru hanya melakukan pembelajaran melalui WhatssApp Grup dengan cara mengirim tugas dan siswa akan mengerjakan dirumah masing-masing. Setelah mengetahui kondisi awal, peneliti kemudian memberikan tindakan kepada siswa kelas V SD N 2 Tanggung melalui proses pembelajaran dengan menerapkan Model Discovery Learning dan berbantu media PowerPoint melalui Google Meet. Setelah melakukan tindakan, peneliti mendapatkan data hasil belajar peserta didik mengalami peningkatan pada setiap siklus, rata-rata nilai peserta didik siklus I pertemuan 1 sebesar 59,23 meningkat menjadi 65,77 pada siklus 1 pertemuan 2, meningkat lagi menjadi 67,31 lalu pada siklus II pertemuan 2 juga mengalami peningkatan menjadi 71,73 . Berlanjut ke siklus III pertemuan 1 yang mengalami peningkatan rata-rata menjadi 73,27 dan pada siklus III pertemuan 2 diperoleh rata-rata 79,23.

Presentase ketuntasan hasil belajar mupel IPA peserta didik pada tema Benda-benda di Sekitar Kita juga terlihat, pada siklus I pertemuan 1 sebesar $27 \%$ meningkat menjadi $46 \%$ pada siklus 1 pertemuan 2, meningkat lagi menjadi $61 \%$ pada siklus II pertemuan 1, lalu pada siklus II pertemuan 2 juga mengalami peningkatan menjadi 73\%. Berlanjut ke siklus III pertemuan 1 yang mengalami peningkatan jumlah siswa yang tuntas menjadi $81 \%$ dan pada siklus III pertemuan 2 diperoleh $100 \%$ peserta didik tuntas dalam belajar IPA pada tema Benda-benda di Sekitar Kita. Berdasarkan data tersebut, pencapaian hasil belajar IPA pada tema Benda-benda di Sekitar Kita pada siklus III petemuan 2 sudah mencapai indikator keberhasilan yaitu sekurang-kurangnya $75 \%$ peserta didik mengalami ketuntasan belajar individual 265 . Berikut ini merupakan tabel perbandingan prosentase peningkatan hasil belajar IPA peserta didik kelas V pada pembelajaran tema 9 :

Tabel 1. Perbandingan Prosentase Peningkatan Hasil Belajar IPA Peserta Didik

\begin{tabular}{|c|c|c|c|c|}
\hline No & Siklus & Pertemuan & Nilai Rata-rata & Prosentase \\
\hline \multirow{2}{*}{1} & \multirow{2}{*}{ I } & Pertama & 59,23 & $27 \%$ \\
\hline & & Kedua & 65,77 & $46 \%$ \\
\hline \multirow{2}{*}{2} & \multirow{2}{*}{ II } & Pertama & 67,31 & $61 \%$ \\
\hline & & Kedua & 71,73 & $73 \%$ \\
\hline 3 & III & Pertama & 73,27 & $81 \%$ \\
\hline
\end{tabular}




\section{Kedua}

79,23

$100 \%$

Adapun grafik perbandingan prosentase peningkatan Hasil belajar IPA kelas V SD Negeri 2 Tanggung dalam pembelajaran Tema 9 pada tabel di atas dapat digambarkan sebagai berikut:

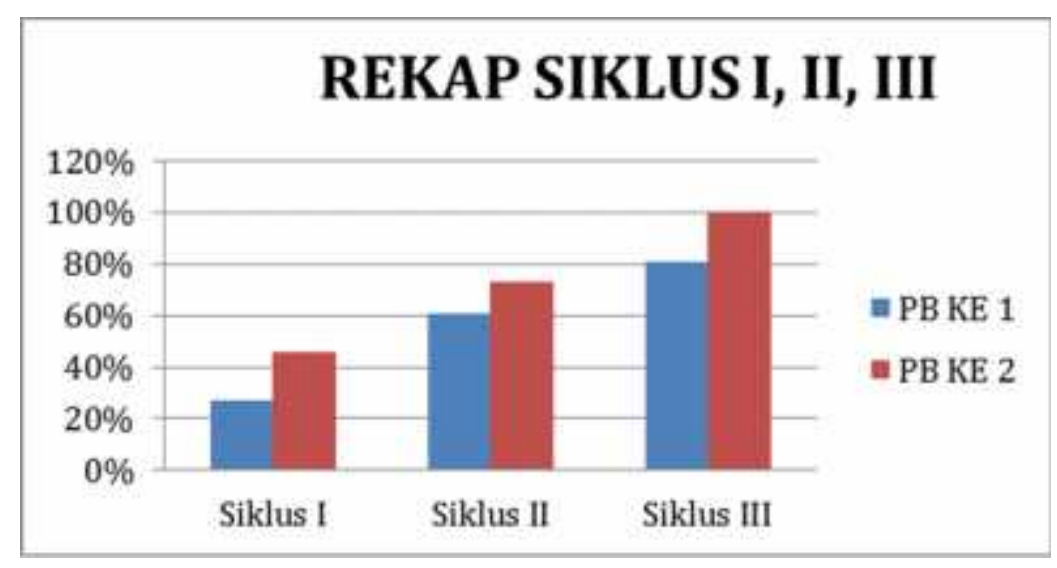

Gambar 1. Perbandingan Prosentase Peningkatan Hasil belajar IPA Peserta Didik

Berdasarkan data diatas dapat dilihat perolehan nilai rata-rata pada siklus I pertemuan 1 sebesar 59,23 dengan prosentase 27\%. Nilai rata-rata siklus I pertemuan 2 sebesar 65,77 dengan prosentase $46 \%$. Nilai rata-rata siklus II pertemuan 1 sebesar 67,31 dengan prosentase $61 \%$. Nilai rata-rata siklus II pertemuan 2 sebesar 71,73 dengan prosentase $73 \%$. Nilai rata-rata siklus III pertemuan 1 sebesar 73,27 dengan prosentase $81 \%$. Nilai rata-rata siklus III pertemuan 2 sebesar 79,23 dengan prosentase 100\%. Presentase ketuntasan hasil belajar siswa pada mupel IPA tema 9 Benda-benda di Sekitar Kita dari siklus 1 sampai siklus ke 3 mengalami kenaikan sebesar $73 \%$. Berdarkan hasil penelitian ini, maka dapat disimpulkan bahwa hipotesis tindakan yaitu dengan menggunakan Model Discovery Learning akan meningkatkan hasil belajar IPA tema 9 pada Kelas V SD N 2 Tanggung Tahun Ajaran 2020/2021 dapat diterima kebenarannya.

\section{Kesimpulan}

Berdasarkan hasil penelitian terhadap hasil belajar IPA peserta didik menggunakan model Discovery Learning pada tema Benda-benda di Sekitar Kita kelas V SD N 2 Tanggung dapat disimpulkan bahwa hasil belajar pada mupel IPA peserta didik mengalami peningkatan. Hal ini sesuai dengan tujuan peneilitian ini yaitu dapat meningkatkan hasil belajar IPA peserta didik kelas V SD N 2 Tanggung. Presentase ketuntasan hasil belajar pada mupel IPA peserta didik dalam Tema 9 Benda-benda di Sekitar Kita juga mengalami kenaikan dari siklus 1 sampai siklus III naik $73 \%$ yaitu dari $27 \%$ pada siklus I menjadi $100 \%$ pada siklus III. Berdasarkan simpulan, maka hipotesis penelitian yaitu dengan menggunakan model pembelajaran Discovery Learning akan meningkatkan hasil belajar IPA tema 9 pada kelas V SDN 2 Tanggung tahun pelajaran 2020/2021 telah terbukti.

\section{Saran}

Saran berdasarkan hasil penelitian ini adalah bagi guru harus dapat menggunakan model pembelajaran yang lebih variatif lagi dan di padukan dengan penggunaan media yang kreatif dan inovatif agar pembelajaran dapat berjalan dengan baik serta dapat meningkatkan hasil belajar siswa. Karena hal ini dapat menentukan kualitas pembelajaran yang dilakukan. Selain itu, siswa juga diharapkan dapat lebih aktif selama proses pembelajaran, siswa lebih berani mengajukan pertanyaan maupun menjawab pertanyaan dari guru sehingga dapat mewujudkan 
tujuan pembelajaran yang akan dicapai dan menghasilkan pembelajaran yang bermakna dan berkualitas. Untuk penelitian selanjutnya diharapkan menggunakan strategi dan media pembelajaran yang lain sebagai alternatif untuk meningkatkan hasil belajar peserta didik.

\section{Daftar Pustaka}

Ahmad Susanto. (2013). Teori Belajar dan Pembelajaran di Sekolah Dasar. Jakarta: Kencana Prenadamedia Group

Arsyad, Azhar. (2014). Media Pembelajaran. Jakarta: PT. Rajagrafindo Persada

Aqib, Zainal. (2010). Penelitian Tindakan Kelas. Bandung: Yrama Widya.

Budiningsih. (2005). Model Discovery Learning. Jakarta: Pustaka Mandiri.

Dimyati \& Mudjiono. 2013. Belajar Dan Pembelajaran. Jakarta: Rineka Cipta.

Fitriana, F. (2019). Penerapan Model Discovery Learning pada Pembelajaran IPA Materi Tekanan untuk Meningkatkan Hasil Belajar Siswa. Jurnal Kependidikan: Jurnal Hasil Penelitian dan Kajian Kepustakaan di Bidang Pendidikan, Pengajaran dan Pembelajaran, 5(2), 100-108. doi:https://doi.org/10.33394/jk.v5i2.1805

Gina Rosarina 1, Ali Sudin, Atep Sujana. (2016) PENERAPAN MODEL DISCOVERY LEARNING UNTUK MENINGKATKAN HASIL BELAJAR SISWA PADA MATERI PERUBAHAN WUJUD BENDA. Jurnal Pena Ilmiah: Vol. 1, No. 1 Program Studi PGSD Kelas UPI Kampus Sumedang

Mundilarto, Rustam. (2004). Penelitian Tindakan Kelas. Jakarta: Dirjen DIKTI Pendidikan Nasional RI.

Mulyasa. (2013). Pengembangan dan Implementasi Kurikulum 2013. Bandung: PT Remaja Rosdakarya Offset.

Nurmiati, B. (2020). Meningkatkan Motivasi dan Hasil Belajar Peserta Didik dengan Mengoptimalkan Penerapan Model Discovery Learning di SD Negeri 2 $\begin{array}{llll}\text { Cakranegara. Jurnal } & \text { Paedagogy, } & 6(1),\end{array}$ doi:https://doi.org/10.33394/jp.v6i1.2523

Nuryaningsih, W. (2021). Penerapan Model Discovery Learning Berkolaborasi Google Classroom dan WhatsApp Group untuk Meningkatkan Kompetensi Siswa dalam Menulis Teks Eksplanasi. Jurnal Paedagogy, $\quad 8(2), \quad$ 159-168. doi:https://doi.org/10.33394/jp.v8i2.3540

Sanaky, H. (2013). Media Pembelajaran Interaktif-Inovatif. Yogyakarta: Kaukaban Dipantara.

Sanjaya, Wina. (2012). Strategi Pembelajaran Berorientasi Standar Proses Pendidikan.Jakarta: Kencana.

Setiarini, A. (2016). Meningkatkan Motivasi dan Hasil Belajar Peserta Didik dengan Mengoptimalkan Penerapan Pendekatan Saintifik Strategi Discovery Learning dan Metode Diskusi di SDN Model Mataram. Jurnal Kependidikan: Jurnal Hasil Penelitian dan Kajian Kepustakaan di Bidang Pendidikan, Pengajaran dan Pembelajaran, 2(1). doi:https://doi.org/10.33394/jk.v2i1.390

Suarni, G., Rizka, M., \& Zinnurain, Z. (2021). Analisis Pengaruh Penerapan Model Pembelajaran Sains Teknologi Masyarakat Terhadap Hasil Belajar Siswa. Jurnal Paedagogy, 8(1), 31-38. doi:https://doi.org/10.33394/jp.v8i1.3226

Susmiati, E. (2020). Meningkatkan Motivasi Belajar Bahasa Indonesia Melalui Penerapan Model Discovery Learning dan Media Video Dalam Kondisi Pandemi Covid-19 bagi Siswa SMPN 2 Gangga. Jurnal Paedagogy, 7(3), 210-215. doi:https://doi.org/10.33394/jp.v7i3.2732 